\title{
OSTEOMETRY OF THE OSSA SESAMOIDEA PHALANGIS PROXIMALIS IN CATTLE (BOS PRIMIGENIUS F. TAURUS LINNÉ 1758)
}

\author{
Č. ČERVENÝ
}

Department of Anatomy, Histology and Embryology, University of Veterinary Science, 61242 Brno

Received Fune 18, 1984

\begin{abstract}
Cervený Č.: Osteometry of the Ossa Sesamoidea Phalangis Proximalis in Cattle (Bos primigenius $f$. taurus Linné 1758). Acta vet. Brno, 54, 1985: 119-128.

The sesamoid bones of the proximal phalanges of the digits from 14 bovine females of the Bohemian Spotted cattle were subject to osteometric examination. Statistical significance of four characteristics was studied. There was no statistical significance in the weight and diameter differences. Highly significant differences were recorded for the maximum height values when comparing the abaxial sesamoid bones of the proximal phalanges of the fourth and third digits from the thoracic limbs and the maximum width when comparing the abaxial sesamoid bones of the proximal phalanges of the third and fourth digits from the pelvic limbs. Also the width values for the abaxial sesamoid bones of the proximal phalanges of the third digits from the thoracic limbs and the abaxial sesamoid bones of the proximal phalanges of the third digits from the pelvic limbs showed highly significant differences. Likewise, the differences in the maximum height values between the abaxial sesamoid bone of the proximal phalanx of the fourth digit and the abaxial sesamoid bone of the proximal phalanx of the third digit on the pelvic limbs showed statistical significance. Similar relations were recorded between the abaxial sesamoid bones of the proximal phalanx of the fourth and third digits on the thoracic limb. Also the difference between the maximum height values of the axial sesamoid bone of the proximal phalanx of the third digit from the thoracic limb and the axial sesamoid bone of the proximal phalanx of the third digit from the thoracic limb and the axial sesamoid bone of the proximal phalanx of the third digit from the pelvic limb was statistically significant. The osteometric findings on the sesamoid bones of the proximal phalanges of the cattle digits form a complement to anatomical characteristics and are another criterion for differentiation and identification of these bones.
\end{abstract}

Cattle, digits, ossa sesamoidea phalangis proximalis, osteometry.

The proximal phalangeal sesamoid bones of digits of cattle, sheep, goat, horse and dog are a regular component of their skeleton (Nickel et al. 1977). In cattle, their ossification centres appear late in the intrauterine life (Vokken and Tarasov, 1968: Lindsay 1969). Červený (1983) found a regular sequence in their appearance. The first to appear is the ossification centre of the axial sesamoid bone of the proximal phalanx of the fourth digit, followed by the ossification centre of the axial sesamoid bone of the proximal phalanx of the third digit and that of the abaxial sesamoid bone of the proximal phalanx of the fourth digit. And the last to appear is the ossification centre of the abaxial sesamoid bone of the third digit. This sequence is common for all limbs, with advanced appearance of ossification centres of the pelvic limbs compared to the thoracic limbs. Basic anatomical data of these small bones in cattle are given in both the classical and modern text books of veterinary anatomy (Martin and Schauder 1934; Kolda 1936; Ellenberger and Baum 1943; Sisson and Grossman 1947; Vokken 1961; Barone 1966; Getty 1975; Nickel et al. 1977). However, the data in these textbooks are not accurate enough to provide criteria for differentiation of the bones and determination of their location and origin with respect to the different digits of the limbs. These problems were discussed by Črvený (1985) who established, on the basis of detailed description of outer characteristics, criteria for their differentiation. The purpose 
of the present paper is to supplement these data with osteometric data. No osteometry of the proximal phalangeal sesamoid bones is available in the classical osteometric literature (D uerst 1930), except osteometry of the os sesamoideum phalangis distalis in the horse described by Driesch (1976). Seeing that we have developed an osteometric method for the ossa sesamoidea phalangis proximalis in cattle and attempted to determine their osteometric characteristics.

\section{Materials and Methods}

For osteometry we used proximal phalangeal sesamoid bones of the digits from all limbs of 14 Bohemian Spotted cattle females from 3 to 12 years. The sampled distal portions of the limbs (metapodia and acropodia) were subject to osteological treatment, i.e. hot water maceration. After thorough bleaching and long-term drying, 6 months at room temperature, the proximal phalangeal sesamoid bones were subject to osteometric treatment. Measurement was based on reliable osteometric methods according to Duerst (1930) which we applied to the proximal phalangeal sesamoid bones of cattle digits.

Table 1

Material used in the study

\begin{tabular}{|c|c|c|c|}
\hline $\begin{array}{c}\text { Sample } \\
\text { No. }\end{array}$ & $\begin{array}{c}\text { Age } \\
\text { years }\end{array}$ & $\begin{array}{c}\text { Body } \\
\text { mass } \\
\text { kg }\end{array}$ & Sex \\
\hline 1 & 6 & 610 & Q \\
\hline 2 & 9 & 530 & 우 \\
\hline 3 & 10 & 575 & ధ \\
\hline 4 & 5 & 567 & 우 \\
\hline 5 & 4 & 712 & q \\
\hline 6 & 12 & 654 & 우 \\
\hline 7 & 4 & 428 & Q \\
\hline 8 & 8 & 567 & $\stackrel{+}{q}$ \\
\hline 9 & 4 & 515 & O \\
\hline 10 & 3 & 430 & o̊ \\
\hline 11 & 7 & 523 & 우 \\
\hline 12 & 5 & 485 & $\frac{1}{2}$ \\
\hline 13 & 9 & 550 & q \\
\hline 14 & 3 & 481 & 오 \\
\hline
\end{tabular}

The fol! ’wing was studied:

1. Maximum height (proximodistal size) - the maximum distance between the facies $\mathrm{m}$. interossei and facies distalis.

2. Maximum width (mediolateral size) - the maximum distance between the facies contactus and facies interdigitalis on the axial, and/or the facies contactus and the facies externa on the abaxial sesamoid bones of the proximal phalanges of the digits.

3. Maximum diameter (length) - a dorsopalmar (plantar) size, the longest distance between the facies articularis and facies flexoria.

4. Mass of the sesamoid bones.

To measure the maximum height and width, the bones were placed on a flat supporting plate with their articular surfaces (their bigger part) down. The measurements were read on a vernier calliper with prism-like points which was placed on the plate in such way as to obtain the maximum height values, centre lines of these distances being perpendicular one to the other.

To measure maximum diameters (lengths), the sesamoid bones were placed on the plate with their facies distalis down and the vernier calliper was placed so as to obtain maximum values of the bone lengths, the centre lines of which were perpendicular to those of the previously measured distances. The abaxial sesamoid bones were easy to place in the position required owing to the developing distal surfaces. The abaxial sesamoid bones, because of their uneven distal surfaces, were fixed in that position with the left hand. 
The mass of the sesamoid bones were determined using analytical balance accurate to one tenth of the gram. The values obtained were recorded in tables and treated statistically. To obtain the different osteometric values we used the main statistical characteristics, i.e. arithmetic mean $(\bar{x})$, standard error of the mean (SEM), standard deviation (SD), coefficient of variation (V) and extent of dispersion (R).

\section{Results}

According to location and origin of the bone with respect to a digit it can be distinguished the axial sesamoid bone of the proximal phalanx of the third digit (in tables given as AX III) and/or of the fourth digit (in Tables given as AX IV), no matter if from the left or right thoracic or pelvic limbs. The abaxial sesamoid bones of the proximal phalanges are located on the respective proximal phalanx and metapodium which is diflected from the axis (AB III in the Tables means the abaxial sesamoid bone of the proximal phalanx of the third digit and AB IV means the abaxial sesamoid bone of the proximal phalanx of the fourth digit, again no matter if from the right or left thoracic or pelvic limb). The shapes and sizes of the different sesamoid bones of the proximal phalanges of the cattle digits were regular enough to permit us to subject them to osteometric measurement.

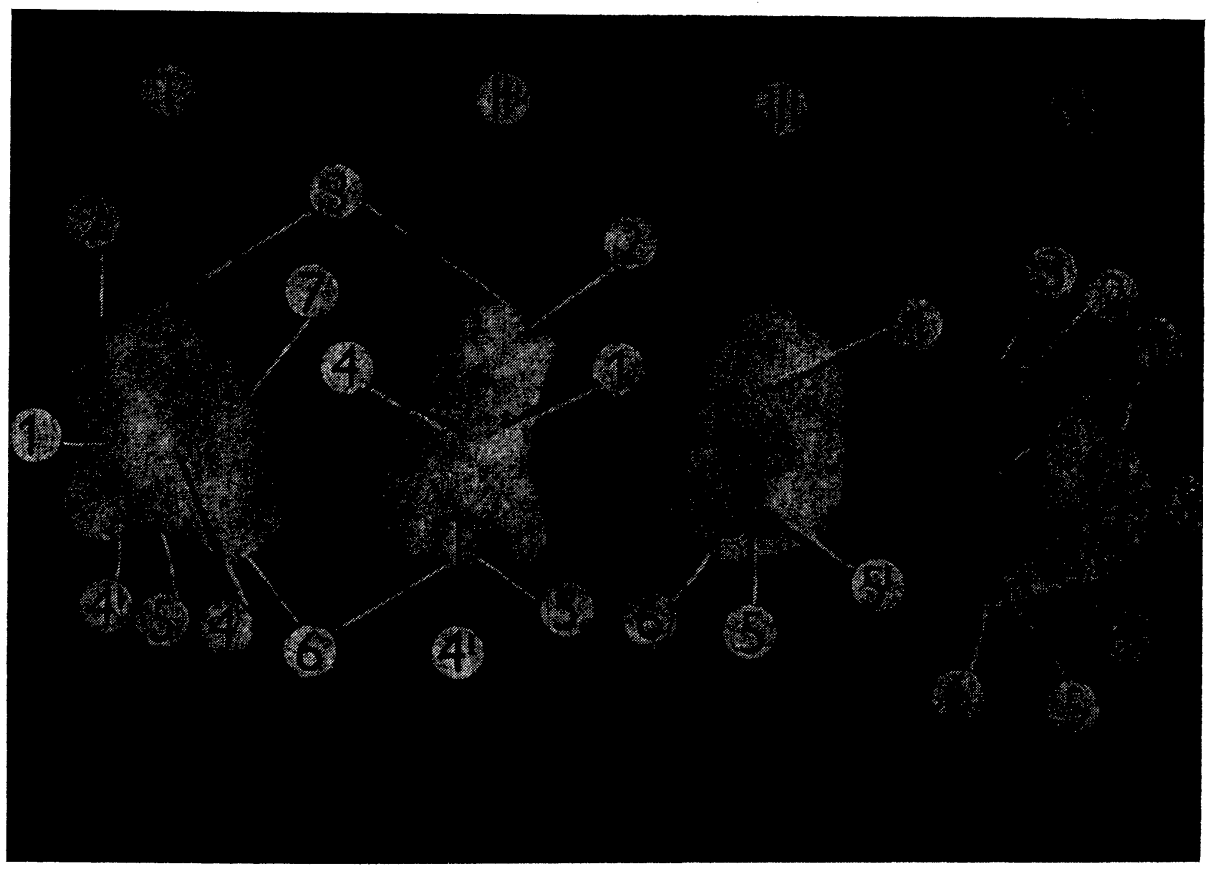

Figure 1

Different shapes of the sesamoid bones of the proximal phalanges of cattle digits.

I - os sesamoideum phalangis proximalis abaxiale of the fourth digit from the right thoracic limb, II - os sesamoideum phalangis proximalis axiale of the fourth digit from the right thoracic limb, III - os sesamoideum phalangis proximalis axiale of the third digit from the right thoracic limb, IV - os sesamoideum phalangis proximalis abaxiale of the third digit from the right thoracic limb, 1 - facies articularis, 2 - facies $m$. interossei, 3 - tuberculum proximale, 4 - facies contactus, 4' - small articular surface, 5 - facies distalis, 5' - small articular surface, 6 - tuberculum distale, 7 - facies flexoria, 8 - tuberculum externum. 
The arithmetic means of the values, including their statistical characteristics are presented in Tables $2,3,4$ and 5 .

Variability of the different characteristics was calculated according to the coefficient of variation (Tables 2, 3, 4 and 5). The weight is one of the most characteristic variable. . Its coefficient of variation ranged between 18.9. and $25.8 \%$. Next comes the maximum diameter (length), with coefficient of variation of $6.28-13.29 \%$. The maximum width appears as the least variable characteristic; its coefficient of variation reached the maximum value of $10.2 \%$.

The statistical evaluation of the different osteometric values was followed by study of significance of the difference of the characteristics measured. The comparison was made on the right thoracic and right pelvic limbs (Fig. 3 and Table 6).

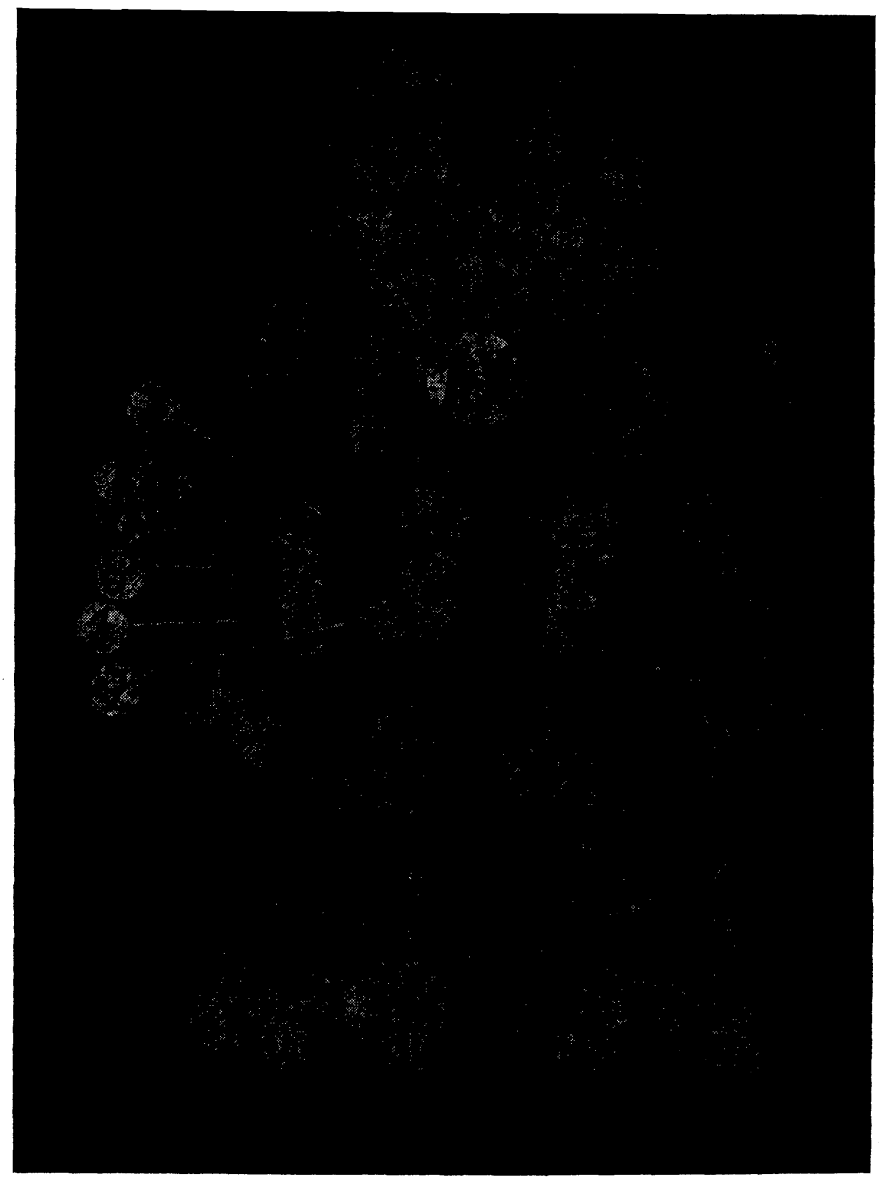

Figure 2

Ossa sesamoidea phalangis proximalis from the right thoracic limb of cattle in the palmar aspect in situ. AX - ossa sesamoidea phalangis proximalis axialia, AB - ossa sesamoidea phalangis proximalis abaxialia, 1 - os sesamoideum phalangis proximalis abaxiale of the third digit, 2 - os sesamoideum phalangis proximalis axiale of the third digit, 3 - os sesamoiseum phalangis proximalis axiale of the fourth digit, 4 - os sesamoideum phalangis proximalis abaxiale of the fourth digit, 5 - facies flexoria, $5^{\prime}$ - tuberculum externum, 6 - facies interdigitalis, 7 - facies contactus, 8 - facies externa, 9 - os metacarpale III et IV, 10 - phalanx proximalis of the fourth digit 
Table 2

Statistical values obtained from the measurement of the right thoracic limb

\begin{tabular}{|c|c|c|c|c|c|c|}
\hline & $\begin{array}{l}\text { Variables } \\
\text { measured }\end{array}$ & $\min , \frac{\mathbf{R}}{-\max }$ & $\bar{x}$ & SEM & SD & $\mathrm{V}(\%)$ \\
\hline $\begin{array}{l}\text { AB } \\
\text { IV. }\end{array}$ & $\begin{array}{l}\text { height } \\
\text { width } \\
\text { length } \\
\text { weight }\end{array}$ & $\begin{array}{r}20,5-25,1 \\
15,1-18,2 \\
15,9-24,8 \\
2.29-6.0\end{array}$ & $\begin{array}{l}23,02 \\
16,52 \\
21,821 \\
4.349\end{array}$ & $\begin{array}{l}0,458 \\
0,269 \\
0,617 \\
0.299\end{array}$ & $\begin{array}{l}1,709 \\
1,006 \\
2,310 \\
1.121\end{array}$ & $\begin{array}{l}7,42 \\
6,09 \\
10,586 \\
25.78\end{array}$ \\
\hline $\begin{array}{l}\text { AX } \\
\text { IV. }\end{array}$ & $\begin{array}{l}\text { height } \\
\text { width } \\
\text { length } \\
\text { weight }\end{array}$ & $\begin{array}{c}21.0-25.9 \\
14.0-20.4 \\
14.0-17.4 \\
2.45-5.59\end{array}$ & $\begin{array}{r}23.65 \\
16.179 \\
16.136 \\
4.302\end{array}$ & $\begin{array}{l}0.445 \\
0.441 \\
0.279 \\
0.266\end{array}$ & $\begin{array}{l}1.666 \\
1.652 \\
1.044 \\
0.995\end{array}$ & $\begin{array}{r}7.04 \\
10.21 \\
6.47 \\
23.13\end{array}$ \\
\hline $\begin{array}{l}\text { AX } \\
\text { III. }\end{array}$ & $\begin{array}{l}\text { height } \\
\text { width } \\
\text { length } \\
\text { weight }\end{array}$ & $\begin{array}{c}20.8-27.5 \\
14.4-16.7 \\
14.2-18.6 \\
2.16-5.67\end{array}$ & $\begin{array}{r}23.900 \\
15.629 \\
16.400 \\
3.981\end{array}$ & $\begin{array}{l}0.475 \\
0.165 \\
0.294 \\
0.252\end{array}$ & $\begin{array}{l}1.780 \\
0.616 \\
1.101 \\
0.944\end{array}$ & $\begin{array}{r}7.44 \\
3.94 \\
6.71 \\
23.71\end{array}$ \\
\hline $\begin{array}{l}\text { AB } \\
\text { III. }\end{array}$ & $\begin{array}{l}\text { height } \\
\text { width } \\
\text { length } \\
\text { weight }\end{array}$ & $\begin{array}{c}17.2-23.2 \\
15.2-18.0 \\
20.0-24.0 \\
2.26-5.21\end{array}$ & $\begin{array}{r}20.714 \\
16.471 \\
21.464 \\
4.089\end{array}$ & $\begin{array}{l}0.507 \\
0.249 \\
0.646 \\
0.264\end{array}$ & $\begin{array}{l}1.898 \\
0.933 \\
2.417 \\
0.988\end{array}$ & $\begin{array}{r}9.16 \\
5.66 \\
11.26 \\
24.16\end{array}$ \\
\hline
\end{tabular}

Height, width and length of the bones are given in $\mathrm{mm}$, weight (mass) is given in $\mathrm{g}$.

Table 3

Statistical values obtained from the measurement of the right pelvic limb

\begin{tabular}{|c|c|c|c|c|c|c|}
\hline & $\begin{array}{l}\text { Variable } \\
\text { measured }\end{array}$ & $\min .{ }^{\mathrm{R}}-\max$. & $\bar{x}$ & SEM & SD & $\mathbf{V}(\%)$ \\
\hline $\begin{array}{l}\mathrm{AB} \\
\text { IV. } \\
\text { IV. }\end{array}$ & $\begin{array}{l}\text { height } \\
\text { width } \\
\text { length } \\
\text { length }\end{array}$ & $\begin{array}{l}18.0-23.3 \\
15.1-17.5 \\
19.1-24.9 \\
19.1-24.9\end{array}$ & $\begin{array}{l}21.279 \\
16.350 \\
22.107 \\
22.107\end{array}$ & $\begin{array}{l}0.458 \\
0.192 \\
0.453 \\
0.453\end{array}$ & $\begin{array}{l}1.715 \\
0.718 \\
1.696 \\
1.696\end{array}$ & $\begin{array}{l}8.05 \\
4.39 \\
7.67 \\
7.67\end{array}$ \\
\hline $\begin{array}{l}\text { AX } \\
\text { IV. }\end{array}$ & $\begin{array}{l}\text { height } \\
\text { width } \\
\text { length } \\
\text { weight }\end{array}$ & $\begin{array}{c}20.1-24.6 \\
14.6-18.8 \\
13.8-18.1 \\
2.48-5.37\end{array}$ & $\begin{array}{r}22.614 \\
16.079 \\
15.907 \\
4.274\end{array}$ & $\begin{array}{l}0.370 \\
0.328 \\
0.479 \\
0.221\end{array}$ & $\begin{array}{l}1.385 \\
1.226 \\
1.795 \\
0.826\end{array}$ & $\begin{array}{r}6.14 \\
7.62 \\
11.28 \\
19.32\end{array}$ \\
\hline $\begin{array}{l}\text { AX } \\
\text { III. }\end{array}$ & $\begin{array}{l}\text { height } \\
\text { width } \\
\text { length } \\
\text { weight }\end{array}$ & $\begin{array}{c}20.2-24.0 \\
14.3-16.7 \\
13.6-18.7 \\
2.24-5.42\end{array}$ & $\begin{array}{r}22.393 \\
15.536 \\
16.493 \\
4.105\end{array}$ & $\begin{array}{l}0.376 \\
0.261 \\
0.586 \\
0.235\end{array}$ & $\begin{array}{l}1.408 \\
0.978 \\
2.193 \\
0.878\end{array}$ & $\begin{array}{r}6.28 \\
6.29 \\
13.29 \\
21.38\end{array}$ \\
\hline $\begin{array}{l}\mathrm{AB} \\
\text { III. }\end{array}$ & $\begin{array}{l}\text { height } \\
\text { width } \\
\text { length } \\
\text { weight }\end{array}$ & $\begin{array}{c}17.4-21.9 \\
15.0-16.9 \\
19.4-23.0 \\
2.11-5.06\end{array}$ & $\begin{array}{r}19.821 \\
15.636 \\
21.450 \\
4.169\end{array}$ & $\begin{array}{l}0.340 \\
0.166 \\
0.390 \\
0.227\end{array}$ & $\begin{array}{l}1.273 \\
0.620 \\
1.462 \\
0.849\end{array}$ & $\begin{array}{r}6.42 \\
-3.96 \\
6.81 \\
20.36\end{array}$ \\
\hline
\end{tabular}

For explanation see Table 2

The majority of significant findings were in differences in the maximum height values. Highly significant was the difference between the values for the abaxial sesamoid bone of the proximal phalanx of the fourth digit and the abaxial sesamoid bone of the proximal phalanx of the third digit on the thoracic limb. Statistically significant differences were also seen between the abaxial sesamoid bone of the proximal phalanx of the fourth digit and the abaxial sesamoid bone of the proximal phalanx of the third digit on the pelvic limbs; between the abaxial sesamoid bone of the proximal phalanx of the fourth digit on the thoracic limb and the abaxial sesamoid bone of the proximal phalanx of the fourth digit on the pelvic limb; between the axial sesamoid bone of the proximal phalanx of the third digit on the thoracic limb and the axial sesamoid bone of the proximal phalanx of the third digit on the pelvic limb. 


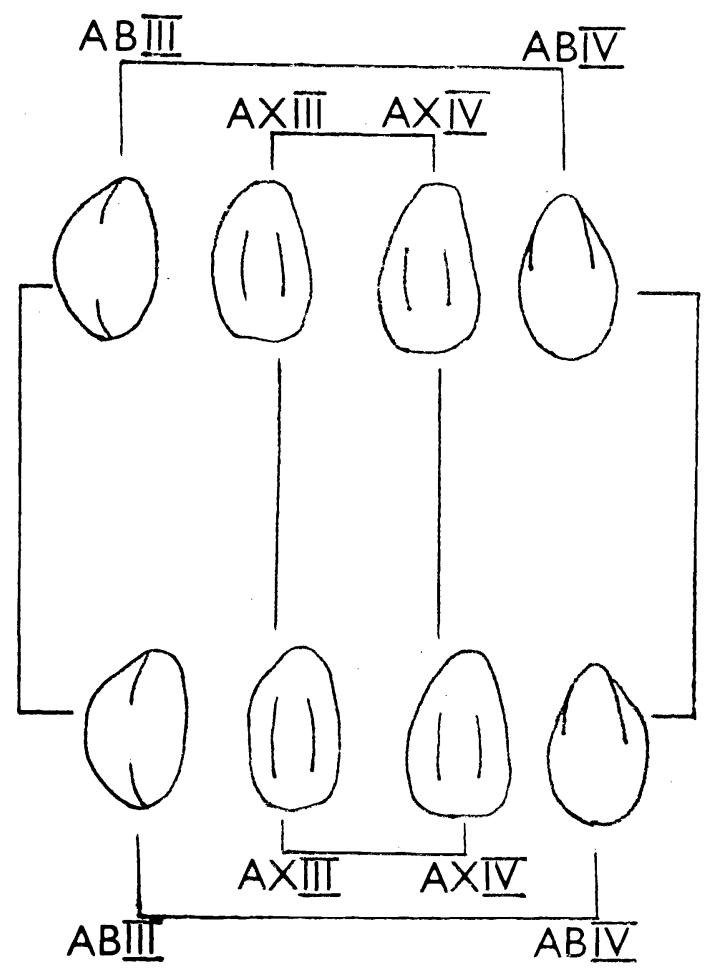

$\mathrm{mp}$

Figure 3

Comparison of osteometric values of the different sesamoid bones of the proximal phalanges of the digits of the thoracic and pelvic limbs. AB III - os sesamoideum phalangis proximalis abaxiale of the third digit, AX III - os sesamoideum phalangis proximalis axiale of the third digit, AX IV - os sesamoideum phalangis proximalis axiale of the fourth digit, AB IV - os sesamoideum phalangis proximalis abaxiale of the fourth digit, $\mathrm{mth}$ - ossa sesamoidea phalangis proximalis membri thoracici, $\mathrm{mp}$ - ossa sesamoidea phalangis proximalis membri pelvini.

The width values showed highly significant differences between: the abaxial sesamoid bone of the proximal phalanx of the fourth digit and the abaxial sesamoid bone of the proximal phalanx of the third digit on the pelvic limb; the abaxial sesamoid bone of the proximal phalanx of the third digit of the thoracic limb and the abaxial sesamoid bone of the proximal phalanx of the third digit of the pelvic limb.

In all groups of bones under study, the differences in the weight and the maximum diameter (length) values were not significant. Neither were significant the differences between the values of all the variables measured of the axial sesamoid bones of the proximal phalanges of the third and fourth digits on both the thoracic and pelvic limbs, except for the values compared of the maximum height of the axial sesamoid bones of the proximal phalanges of the third digits from the thoracic and pelvic limbs.

It can be concluded that it is possible, on the basis of osteometric values, to differentiate some of the sesamoid bones of the proximal phalanges of the digits. The proximo- 
distal distance (the maximum height of the bone) can be employed for determination of the origin of the abaxial sesamoid bones of the proximal phalanges of the third or fourth digit of the thoracic limb. In the abaxial sesamoid bones from the pelvic limbs it is possible to use, apart from the maximum height, also the mediolateral distance (the maximum width of the bone). The abaxial sesamoid bones of the proximal phalanges of the digits from the thoracic and pelvic limbs can be differentiated on the basis of the maximum height - in the abaxial sesamoid bones of the proximal phalanx of the fourth digit and the maximum width - in the abaxial sesamoid bone of the proximal

Table 4

Statistical values obtained from the measurement of the left thoracic limb

\begin{tabular}{|c|c|c|c|c|c|c|}
\hline & $\begin{array}{l}\text { Variables } \\
\text { measured }\end{array}$ & $\min . \frac{\mathrm{R}}{-} \max$. & $\bar{x}$ & SEM & SD & $V(\%)$ \\
\hline $\begin{array}{l}\text { AB } \\
\text { IV. }\end{array}$ & $\begin{array}{l}\text { height } \\
\text { width } \\
\text { length } \\
\text { weight }\end{array}$ & $\begin{array}{c}20.5-25.6 \\
14.9-18.3 \\
19.4-24.6 \\
2.63-6.09\end{array}$ & $\begin{array}{r}23.157 \\
16.664 \\
22.186 \\
4.411\end{array}$ & $\begin{array}{l}0.431 \\
0.255 \\
0.478 \\
0.290\end{array}$ & $\begin{array}{l}1.612 \\
0.956 \\
1.791 \\
1.087\end{array}$ & $\begin{array}{r}6.96 \\
5.73 \\
8.07 \\
24.64\end{array}$ \\
\hline $\begin{array}{l}\text { AX } \\
\text { IV. }\end{array}$ & $\begin{array}{l}\text { height } \\
\text { width } \\
\text { length } \\
\text { weight }\end{array}$ & $\begin{array}{c}21.8-26.4 \\
14.3-17.6 \\
14.1-18.5 \\
2.46-5.41\end{array}$ & $\begin{array}{r}23.800 \\
15.700 \\
16.664 \\
4.286\end{array}$ & $\begin{array}{l}0.416 \\
0.278 \\
0.348 \\
0.278\end{array}$ & $\begin{array}{l}1.558 \\
1.039 \\
1.304 \\
0.039\end{array}$ & $\begin{array}{r}6.54 \\
6.61 \\
7.82 \\
24.24\end{array}$ \\
\hline $\begin{array}{l}\text { AX } \\
\text { III. }\end{array}$ & $\begin{array}{l}\text { height } \\
\text { width } \\
\text { length } \\
\text { weight }\end{array}$ & $\begin{array}{c}21.1-27.3 \\
14.3-16.7 \\
14.1-17.6 \\
2.32-5.71\end{array}$ & $\begin{array}{r}24.043 \\
15.664 \\
16.229 \\
4.017\end{array}$ & $\begin{array}{l}0.478 \\
0.192 \\
0.249 \\
0.254\end{array}$ & $\begin{array}{l}1.790 \\
0.720 \\
0.931 \\
0.950\end{array}$ & $\begin{array}{r}7.44 \\
4.59 \\
5.73 \\
23.64\end{array}$ \\
\hline $\begin{array}{l}\text { AB } \\
\text { III. }\end{array}$ & $\begin{array}{l}\text { height } \\
\text { width } \\
\text { length } \\
\text { weight }\end{array}$ & $\begin{array}{c}17.8-23.4 \\
15.6-21.2 \\
20.0-23.5 \\
2.25-5.77\end{array}$ & $\begin{array}{r}20.936 \\
17.064 \\
22.150 \\
4.129\end{array}$ & $\begin{array}{l}0.496 \\
0.381 \\
0.405 \\
0.266\end{array}$ & $\begin{array}{l}1.857 \\
1.426 \\
1.516 \\
0.997\end{array}$ & $\begin{array}{r}8.86 \\
8.35 \\
6.84 \\
24.14\end{array}$ \\
\hline
\end{tabular}

For explanation see Table 2

Table 5

Statistical values obtained from the measurement of the left pelvic limb

\begin{tabular}{|c|c|c|c|c|c|c|}
\hline & $\begin{array}{l}\text { Variables } \\
\text { measured }\end{array}$ & $\min . \frac{\mathrm{R}}{-\max .}$ & $\bar{x}$ & SEM & $\mathrm{SD}$ & V (\%) \\
\hline $\begin{array}{l}\text { AB } \\
\text { IV. }\end{array}$ & $\begin{array}{l}\text { height } \\
\text { width } \\
\text { length } \\
\text { weight }\end{array}$ & $\begin{array}{c}17.6-22.9 \\
14.9-17.2 \\
19.1-24.2 \\
2.49-5.51\end{array}$ & $\begin{array}{r}20.921 \\
16.179 \\
21.907 \\
4.401\end{array}$ & $\begin{array}{l}0.433 \\
0.188 \\
0.405 \\
0.238\end{array}$ & $\begin{array}{l}1.622 \\
0.704 \\
1.517 \\
0.893\end{array}$ & $\begin{array}{r}7.75 \\
4.35 \\
6.92 \\
20.29\end{array}$ \\
\hline $\begin{array}{l}\text { AX } \\
\text { IV. }\end{array}$ & $\begin{array}{l}\text { height } \\
\text { width } \\
\text { length } \\
\text { weight }\end{array}$ & $\begin{array}{c}19.7-23.8 \\
15.0-17.9 \\
14.4-18.2 \\
2.60-5.49\end{array}$ & $\begin{array}{r}22.529 \\
16.100 \\
15.871 \\
4.305\end{array}$ & $\begin{array}{l}0.378 \\
0.295 \\
0.410 \\
0.840\end{array}$ & $\begin{array}{l}1.413 \\
1.104 \\
1.537 \\
0.224\end{array}$ & $\begin{array}{r}6.27 \\
6.85 \\
9.68 \\
19.51\end{array}$ \\
\hline $\begin{array}{l}\text { AX } \\
\text { III. }\end{array}$ & $\begin{array}{l}\text { height } \\
\text { width } \\
\text { length } \\
\text { weight }\end{array}$ & $\begin{array}{r}19.8-23.8 \\
14.5-17.9 \\
13.5-18.0 \\
2.30-5.18\end{array}$ & $\begin{array}{r}22.321 \\
15.464 \\
15.793 \\
4.108\end{array}$ & $\begin{array}{l}0.364 \\
0.253 \\
0.380 \\
0.234\end{array}$ & $\begin{array}{l}1.362 \\
0.948 \\
1.425 \\
0.875\end{array}$ & $\begin{array}{r}6.10 \\
6.09 \\
9.02 \\
21.29\end{array}$ \\
\hline $\begin{array}{l}\mathrm{AB} \\
\text { III. }\end{array}$ & $\begin{array}{l}\text { height } \\
\text { width } \\
\text { length } \\
\text { weight }\end{array}$ & $\begin{array}{c}17.2-21.5 \\
14.8-17.0 \\
20.0-24.2 \\
2.51-4.90\end{array}$ & $\begin{array}{r}20.093 \\
15.793 \\
21.807 \\
4.124\end{array}$ & $\begin{array}{l}0.381 \\
0.194 \\
0.366 \\
0.208\end{array}$ & $\begin{array}{l}1.427 \\
0.729 \\
1.370 \\
0.780\end{array}$ & $\begin{array}{r}7.10 \\
4.61 \\
6.28 \\
18.91\end{array}$ \\
\hline
\end{tabular}

For explanation see Table 2 
Table 6

Statistical significance in the characteristics studied using the t-test.

(Comparison of the osteometric values of the proximal phalangeal sesamoid bones of the digits from the right thoracic $(\mathrm{PH})$ and right pelvic (PP) limbs)

\begin{tabular}{|l|c|c|c|c|}
\hline \multicolumn{1}{|c|}{ Bones under comparison } & height & width & length & weight \\
\hline AB IV. PH + AB III. PH & $\begin{array}{c}\text { highly } \\
\text { significant } \\
\text { AB IV. PP + AB III. PP }\end{array}$ & significant & $\begin{array}{c}\text { highly } \\
\text { significant }\end{array}$ & 0 \\
AX IV. PH + AX III. PH & 0 & 0 & 0 \\
AX IV. PP + AX III. PP & 0 & 0 & 0 \\
AB III. PH + AB III. PP & 0 & 0 & 0 \\
AB IV. PH + AB IV. PP & significant & significant & 0 & 0 \\
AX III. PH + AX III. PP & significant & 0 & 0 & 0 \\
AX IV. PH + AX IV. PP & 0 & 0 & 0 \\
\hline
\end{tabular}

phalanx of the third digit. The origin of the axial sesamoid bone of the proximal phalanx of the third digit from the theracic or pelvic limb can be determined from comparison of the maximum heights of the bones. The other osteometric values studied cannot be utilized for determination of the axial sesamoid bones of the proximal phalanges.

\section{Discussion}

It is suggested that the osteometric values obtained from measurement of the population studied of the proximal phalangeal sesamoid bones of the cattle digits show differences which can provide further criteria for differentiation of these bones. The contradictory data of different sizes of the axial and abaxial sesamoid bones of the proximal phalanges of the digits, as reported by Kold a (1936) on one hand and Vokken et al. (1961) on the other, provide little knowledge of anatomy of these bones. Červený (1985) determined, on the basis of a detailed anatomical description, a number of characteristics of the ossa sesamoidea phalangis proximalis in cattle. He reported that characteristics differentiating the axial sesamoid bones of the proximal phalanges from the abaxial ones, i.e. their anatomy and shape, are quite obvious. Therefore we did not compare their osteometric values. Similarly, as there are differences between anatomical characteristics of the abaxial sesamoid bones of the proximal phalanges of the third and fourth digits from the thoracic and those from the pelvic limbs (Cervený 1984), the osteometric values of these bones show differences, too. At least one distance measured in these bones showed statistically significant values and thus provided another criterion for determination of these bones. According to Cervený (1984), the origin of the axial sesamoid bones of the proximal phalanges of both the fourth and third digits from the thoracic or pelvic limb can be determined on the basis of different shape of their tuberculum proximale. The osteometric values obtained from measuring the axial sesamoid bones permit to determine the origin of the axial sesamoid bone of the proximal phalanx only of the third digit from the thoracic and pelvic limbs. Thus the osteometric method cannot be used for determination of origin of the axial sesamoid bones with respect to their digits, left - side or 
'right - side limb, and determination of origin of the axial sesamoid bone of the proximal phalanx of the fourth digit with respect to the thoracic or pelvic limb. These sesamoid bones can be differentiated only indirectly according to topographoanatomical interrelations as described by Cervený (1984), on condition that one of the data looked for to determine the origin of the bone is known.

The osteometric characteristics studied in the present paper are a supplement to anatomical characteristics. The results of the osteometric examination, high variability of the weight and the maximum diameter values for the bones and the lowest variability of the maximum width are in accordance with the osteometric values reported in the literature for different bones of the skeleton (Jablokov 1966).

\section{Osteometric ossa sesamoidea phalangis proximalis u skotu (Bos primigenius f. taurus Linné 1758)}

Prověřili jsme ostcometricky sezamské kosti proximálních článkủ prstủ čtrnácti jedincủ skotu plemene českého červenostrakatého, samičího pohlaví. Sledovali jsme statistickou závislost čtyř znaků. Studované kosti se neliší v hmotnosti a prủměru. Zjistili jsme vysoce statisticky prủkaznou rozdílnost pro hodnoty maximální výšky při porovnání abaxiálních sezamských kostí proximálních článkủ čtvrtých a třetích prstů na hrudních končetinách a maximální šířky při porovnání abaxiálních sezamských kostí proximálních článkủ třetích a čtvrtých prstů na pánevních končetinách. Vysoce statisticky prủkaznou rozdílnost jsme zjistili též při porovnání šiřky abaxiálních sezamských kostí proximálních článkủ třetích prstủ hrudních končetin a abaxiálních sezamských kostí proximálních článkủ třetích prstủ pánevních končetin. Ștatisticky průkazné jsou rozdíly hodnot maximální výšky mezi abaxiální sezamskou kostí proximálního článku čtvrtého prstu a abaxiální sezamskou kostí proximálního článku třetího prstu na pánevní končetině. Tytéž vztahy jsme zjistili i mezi abaxiální sezamskou kostí proximálního článku čtvrtého prstu a abaxiální sezamskou kostí proximálního článku třetího prstu na hrudní končetině. Statisticky průkazný je též rozdíl hodnot maximální výšky mezi axiální sezamskou kostí proximálního článku třetího prstu hrudní končetiny a axiální sezamskou kostí proximálního článku tṛ̌tího prstu pánevní končetiny. Osteometrická zjišstění na sezamských kostech proximálních článků prstů skotu doplňují anatomické znaky, takže jsou dalším výzzamným kriteriem pro vzájemné rozlišení a identifikaci těchto kostí.

\section{Остеометрия оssa sesamoidea phalangis proximalis крупного рогатого скота (Bos primigenius f. taurus Linné 1758)}

Остеомстрически проверялись сесамовидные кости проксимальных фаланг четырнадцати голов крупного рогатого скота чешской красно-пестрой породы - самок. Проводились наблюдения за статистической зависимостью четырех признаков. Изучаемые кости не отличаются массой и диаметром. Была установлена высокая статистическая значимость разности величин максимальной высоты при оравнении абаксиальных сесамовидных костей проксимальных фраланг четвертого и третьего пальцев на грудных конечностях и максимальной ширины при сравнении абаксиальных сесамовидных костей проксимальных фаланг третьего и четвер- 
того пальцев на тазовых конечностях. Большую статистически значимую. разность установили также при сравнении ширины абаксиальных сесамовидных костей проксимальных фаланг третьих пальцев грудных конечностей и абаксиальных сесамовидных костей проксимальных фаланг третьих пальцев тазовых конечностей. Статистически доказательной является разность величин максимальной высоты между абаксиальной сесамовидной костью проксимальной фаланги третьего пальца на тазовой конечности. Те же самые отношения были обнаружены между абаксиальной сесамовидной костью проксимальной фаланги четвертого пальца и абаксимальной сесамовидной костью проксимальной фаланги третьего пальца грудной конечности. Статистически доказательной является также разность между аксиальной сесамовидной костью прокоимальной фаланги третьего пальца грудной конечности и аксиальной сесамовидной костью проксимальной фаланги третьего пальца тазовой конечности.

\section{References}

BARONE, R.: Anatomie comparée des Mammiferes domestiques. Tome rremier, Osteologie. Lab, D'anatomie ecole national veterinaire, Lyon $1966,811 \mathrm{pp}$.

CERVENÝ, C.: The development and ossification of the ossa sesamoidea phalangis proximalis in the cattle (Bos primigenius f. taurus Linné 1758). Acta vet. Brno, 52, 1983, 27-38.

CERVENÝ, Č.: Anatomical characteristics of the ossa sesamoidea phalangis proximalis in cattle (Bos primigenius $\mathrm{f}$. taurus Linné 1758). Acta vet. Brno, 54, 1985, 3-22.

DRIESCH, A.: Das Vermessen von Tierl:nochen aus vor - und frühgeschicltlichen Siedlungen. Univ. München, München 1976, $114 \mathrm{pp}$.

DUERST, J. U.: Vergleichende Untersuchungsmethoden am Skelett bei Säugern. In ABDERHALDEN, E.: Handbuch der Biologischen Arbeitsmethoden. Methoden der vergleichenden morphologischen Forschlung, Teil 1., 125-530. Urban u. Schwarzenberg, Berlin-Wien 1930, $887 \mathrm{pp}$.

ELLENBERGER, W. - BAUM, H.: Handbuch der vergleichenden Anatomie der Haustiere. Springer Verlag, Berlin 1943, 1155 pp.

GETTY, R.: Sisson and Grossman's Anatomy of the Domestic Animals. W. S. Saunders Company, Philadelphia, London, Toronto $1975,1211 \mathrm{pp}$.

JABLOKOV, A. V.: Izmenšivost mlekopitajuščich. Izd. Nauka, Moskva 1966, 363 pp.

KOLDA, J.: Srovnávací anatomie zviŕat domácích se zřetelem $\mathrm{k}$ anatomii člověka. I. část obecná, II. nauka o kostech a chrupavkách. Novina, Brno 1936, 914 pp.

LINDSAY, F. E. F.: Observations on the loci of ossification in the prenatal and neonatal bovine skeleton. I. Appendicular skeleton. Brit. Vet. J., 125, 1969, 101-111.

MARTIN, P. - SCHAUDER, W.: Lehrbuch der Anatomie der Haustiere. Band III., I. Teil: Bewegungsapparat der Hauswiederkäuer. Schickhardt und Ebner, Stuttgart 1934, 135 pp.

NICKEL, R. - SCHUMMER, A. - SEIFERLE, E.: Lehrbuch der Anatomie der Haustiere. Band I. Bewegungsapparat. Paul Parey, Berlin und Hamburg 1977, 539 pp.

SISSON, S. - GROSSMAN, J. D.: The anatomy of the domestic animals. W. B. Saunders Company, London 1947, $972 \mathrm{pp}$.

VOKKEN, G. G. - GLAGOLEV, S. N. - BOGOLJUBSKIJ, S. N.: Anatomija domašnich i životnych. Tom. I. Gos. izd. "Vysšaja škola", Moskva 1961, 390 pp.

VOKKEN, G. G. - TARASOV, S. S.: Osnovnyje zakonoměrnosti okostěněnija skeleta tulovišča i konečnostěj domašnich životnych. Arch. anat. gist. i embryol., 55, 1968, 8-13. 